\title{
The Development of STEM Literacy Using the Learning Process of Scientific Imagineering through AR
}

\author{
https://doi.org/10.3991/ijet.v13i01.7664 \\ Somsak Techakosit $\left({ }^{\varpi}\right)$ \\ Kasetsart University, Bangkok, Thailand \\ techakosit@gmail.com \\ Prachyanun Nilsook \\ King Mongkut's University of Technology North Bangkok, Bangkok, Thailand
}

\begin{abstract}
The aim of this research was to 1) study the elements of STEM (scientific, technological, engineering, and mathematical) literacy for the learning process of SIGAR (Scientific Imagineering through Augmented Reality) and 2) study the development of STEM literacy by using the learning process of SIGAR. The research methodology was divided into two phases: 1) reviewing literature on STEM literacy and studying each step of the learning process of SIGAR. 2) Examining the suitability of the elements of STEM literacy and the development of STEM literacy by using the learning process of SIGAR. The evaluation was undertaken by ten experts who hold doctoral degrees. The results showed that STEM literacy consisted of: 1) the ability to identify STEM problems, 2) the ability to seek new knowledge, 3) the application of the STEM concept, 4) the ability to solve problems using STEM, 5) the ability to communicate information relating to STEM, and 6) the ability to make decisions based on STEM. The experts also evaluated which step of the learning process of SIGAR was most suitable for the development of the respective aspects of STEM literacy.
\end{abstract}

Keywords-STEM Literacy, Scientific Imagineering, Augmented Reality

\section{$1 \quad$ Introduction}

Modern economies require workers who have the knowledge and skills to compete with others, problem-solvers, innovators, and inventors, as well as those who are able to rely on themselves and think rationally. Such workers are one of the important factors in enhancing a country's innovative capacity. The key to the development of these skills is the promotion of scientific, technological, engineering, and mathematical skills (STEM) among students in basic education [1]. In recent years, educational leaders in the United States have been trying to strengthen scientific, technological, engineering and mathematical education nationwide in order to achieve the following goals: 1) enhance the capacity of all students in the STEM fields; and 2) increase the 
number of students who continue to work in the STEM fields and proceed to higher education in such fields [2].

STEM has its origins in the 1990s, at the National Science Foundation (NSF) [3]. STEM should be taught in an integrated and cross curricular manner, not just in "silos" where the individual subject areas dominate and other subjects are only afterthoughts [4]. STEM subject areas are crucial to providing a nation of innovative thinkers who will create new inventions [5].

STEM Education is an educational programme with the study of science, technology, engineering and mathematics embedded in its core objectives, in order to strengthen the education in these subject areas from primary and secondary education through to $\mathrm{PhD}$, as well as adult education [6]. STEM education is the input which teachers deliver to students, while STEM literacy is the outcome which is developed by the students. This includes the knowledge, skills, and attitudes they gain as a result of participating in STEM education [7]. STEM literacy is crucial for students who will enter the labour market, as it is the core competency of twenty-first century workers. Therefore, students must be advanced problem-solvers, innovators, technology specialists and well-educated people [5].

STEM literacy is defined as the knowledge and understanding of scientific and mathematical concepts and the process required for personal decision-making, participation in civic and cultural affairs, and economic productivity for all students [8].

STEM literacy should not be viewed as a content area, but as a deictic means composed of skills, abilities, factual knowledge, procedures, concepts, and metacognitive capacities to gain further learning [9].

Augmented reality (AR) is a type of virtual reality (VR) which allows a user to see simulated objects overlaying or supplementing a real-world environment [10]. The simulated object can be in 2D and 3D forms, e.g. a sound file, video, or text information, and the user can perceive the additional content in a real-world environment [11]. As technological advancement has rendered AR more efficient and ARcompatible devices, such as PCs and mobile phones have become small and compact, AR tends to be used more frequently in teaching [12]. The following characteristics of AR make it suitable for teaching: 1) it is flexible and able to be used in variety of activities according to the context of the content; 2) it interacts with users by allowing students to observe digital objects in a real-world environment; 3) it increases learning efficiency by transforming abstract ideas into concrete existence, encouraging students to learn freely; 4) it is a convenient tool for learning anywhere, at any time; 5) it inspires the users to learn by adding liveliness to plain objects; and 6) it promotes cooperative learning among students or between students and teachers [13].

'Imagineering' is a portmanteau of two key words - imagine and engineering [14]. It could be said that Imagineering is a tool to turn imagination into reality, which does not exist today [15] and it is the process Imagineers use to turn tacit knowledge into working knowledge [16]. 
Techakosit and Nilsook [13] proposed the learning process of Scientific Imagineering through Augmented Reality (SIGAR). It is a learning process that combines Imagineering, scientific method and an AR learning environment. The six steps of SIGAR are:

1. imagine,

2. study and research,

3. design,

4. develop,

5. present, and

6. evaluate.

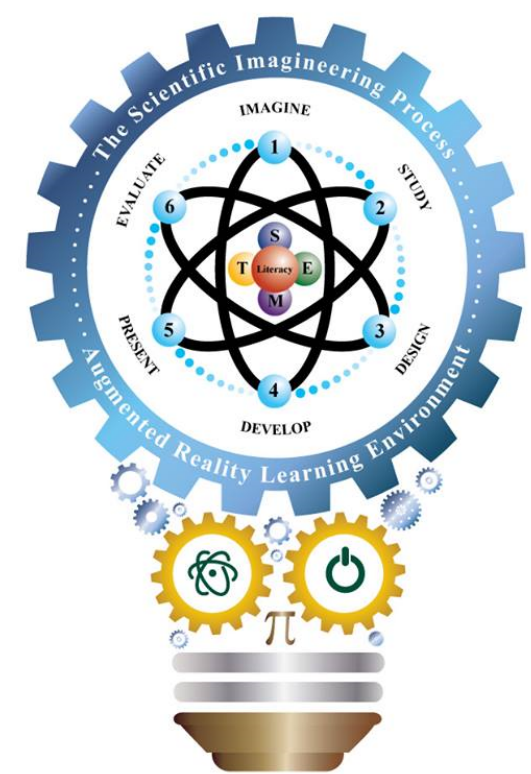

Fig. 1. The learning process of Scientific Imagineering through Augmented Reality [13]

Techakosit and Nilsook [13] suggested that SIGAR could be used to develop the student's STEM literacy. This study investigated the elements of STEM literacy and the development of STEM literacy during each step of SIGAR.

\section{Objective}

The objectives of this research were to:

1. Study the elements of STEM literacy for SIGAR

2. Study the development of STEM literacy by using SIGAR activities 


\section{$3 \quad$ Methodology}

The research methodology was divided into two phases as follows:

Phase 1 Studying the elements of STEM literacy and the learning process of Scientific Imagineering through AR in order to enhance STEM literacy. The phase included:

1. Reviewing literature on STEM literacy written by The Connectory [17], Deborah B Sorgi [18], National Governors Association [1], Rodger W Bybee [3], Şenay Purzer, Johannes Strobel, and Monica E Cardella [19], Washington STEM Study Group [20] and Yoojung Chae, Senay Purzer and Monica Cardella [21], to synthesize the elements of STEM literacy.

2. Studying Techakosit and Nilsook's learning model of Scientific Imagineering through AR in order to enhance STEM literacy [13] to set activities for teachers and students in each step of the learning model and define the elements of STEM literacy which are the output of each step of the learning model.

Phase 2 Evaluating the suitability of the defined STEM literacy and SIGAR activities. The phase included:

1. Creating a tool for evaluating the suitability of STEM literacy elements and SIGAR activities.

2. Proposing the development of STEM literacy factors and the learning process of Scientific Imagineering through AR activities in order to enhance STEM literacy to ten experts who hold doctoral degrees, work as lecturers at universities and have at least ten years' relevant experience. These experts consisted of four experts in STEM disciplinary subjects, three experts in science education and three experts in technological education, who considered and evaluated the suitability.

3. Analysing the results of the evaluation of the suitability of STEM literacy elements and SIGAR activities using mean $(x)$ and standard deviation (S.D.). A five point Likert scale was used to determine the activities' level of suitability.

\section{$4 \quad$ Results}

The result of documentary research on the meaning of STEM literacy to synthesize elements of STEM literacy is shown in Table 1.

1. the ability to identify STEM problems, referring to the ability to generate scientific, technological, engineering or mathematical problems or questions in a realworld context and seek answers for such problems or questions using a scientific, technological, engineering or mathematical process, as well as the ability to identify evidence, eyewitnesses or information required to respond to the problems or questions;

2. the ability to seek new knowledge, referring to the ability to specify the set of questions which would be used as guidelines when finding the answers, the ability to synthesize information from multiple sources efficiently and reliably; 
Table 1. Documentary research on the meaning of STEM literacy

\begin{tabular}{|c|c|c|c|c|c|c|c|}
\hline STEM Literacy Elements & 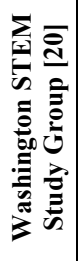 & 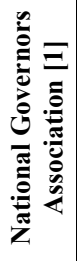 & $\begin{array}{l}\bar{m} \\
\text { D. } \\
\text { D. }\end{array}$ & 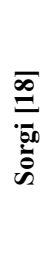 & 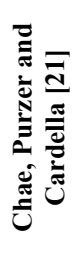 & 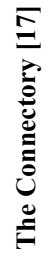 & 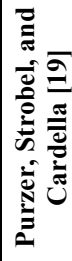 \\
\hline Ability to identify STEM problems & $\checkmark$ & $\checkmark$ & $\checkmark$ & $\checkmark$ & & & \\
\hline Ability to seek new knowledge & & $\checkmark$ & $\checkmark$ & & & $\checkmark$ & \\
\hline Application of STEM concepts & $\checkmark$ & & $\checkmark$ & $\checkmark$ & & & \\
\hline Ability to solve problems using STEM & $\checkmark$ & & & $\checkmark$ & $\checkmark$ & $\checkmark$ & $\checkmark$ \\
\hline $\begin{array}{l}\text { Ability to communicate the information relating to } \\
\text { STEM }\end{array}$ & & & & $\checkmark$ & & $\checkmark$ & $\checkmark$ \\
\hline Ability to make decisions based on STEM & & & & & $\checkmark$ & $\checkmark$ & $\checkmark$ \\
\hline
\end{tabular}

3. the application of STEM concepts, referring to the ability to apply scientific, technological, engineering and mathematical concepts and processes to daily life situations while taking into account any effect that might occur;

4. the ability to solve problems using STEM, referring to the ability to select suitable scientific, technological, engineering and mathematical tools and processes to help solve complex problems with advanced thinking skills;

5. the ability to communicate information relating to STEM, referring to the ability to effectively present and perceive scientific, technological, engineering and mathematical information and knowledge, and

6. the ability to make decisions based on STEM, referring to the ability to describe, criticise, make comments and make decisions about complex issues in the modern world using scientific, technological, engineering and mathematical principles and processes. The elements of STEM literacy are shown in Figure 2.

Each element of STEM literacy could be developed during each step of Techakosit and Nilsook's SIGAR [13] as shown in figure 3.

Imagine: The teacher inspired the students by using AR to display an event and having them ask questions about the event they observed. The questions asked had to be those that could be answered using the STEM process. This step of SIGAR encouraged the students to develop their ability to identify STEM problems.

Study and research: The students brainstormed to identify the topics that had to be researched in order to respond to the questions and problems in the first step. The teacher provided AR media, which encouraged the students to study and research by themselves so that they could develop their ability to seek new knowledge.

Design: The students role-played as engineers who were assigned by the teacher to invent an object according to the teacher's requirements and criteria, while using the knowledge gained from the previous step. The teacher provided AR media allowing the students to contact experts for advice while designing the object, so that they could develop their ability to apply STEM concepts. 


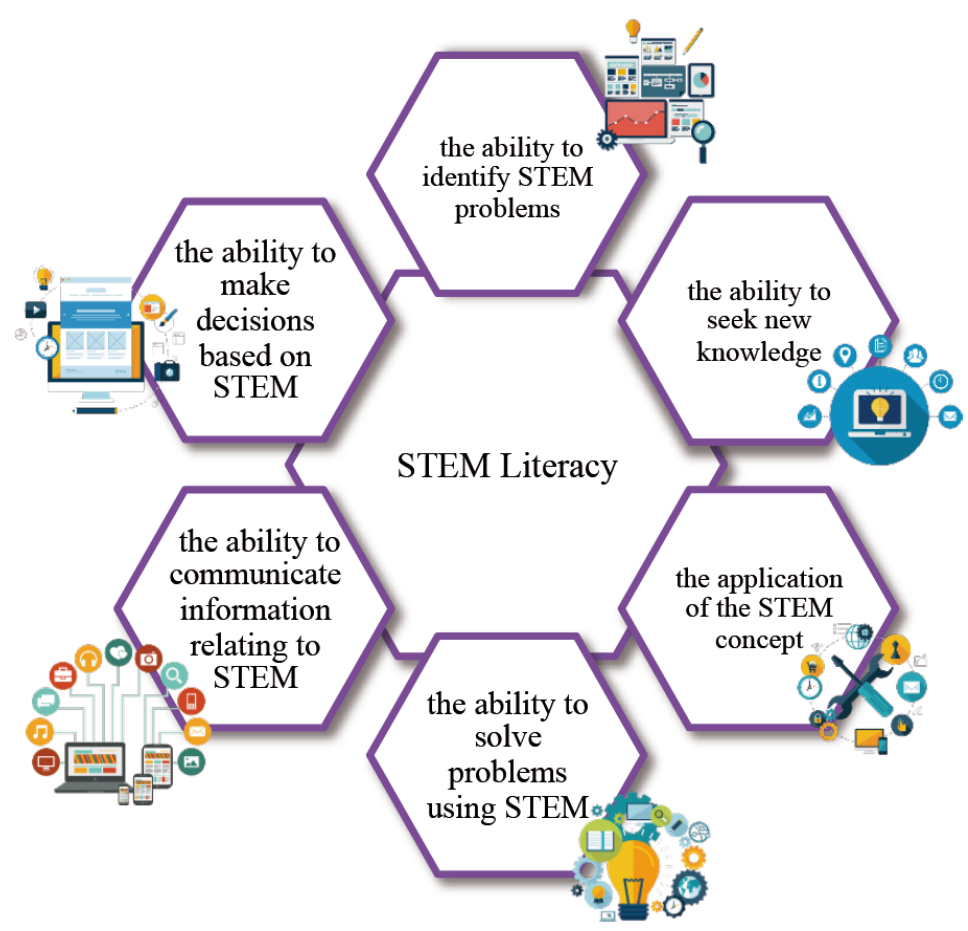

Fig. 2. Elements of STEM literacy

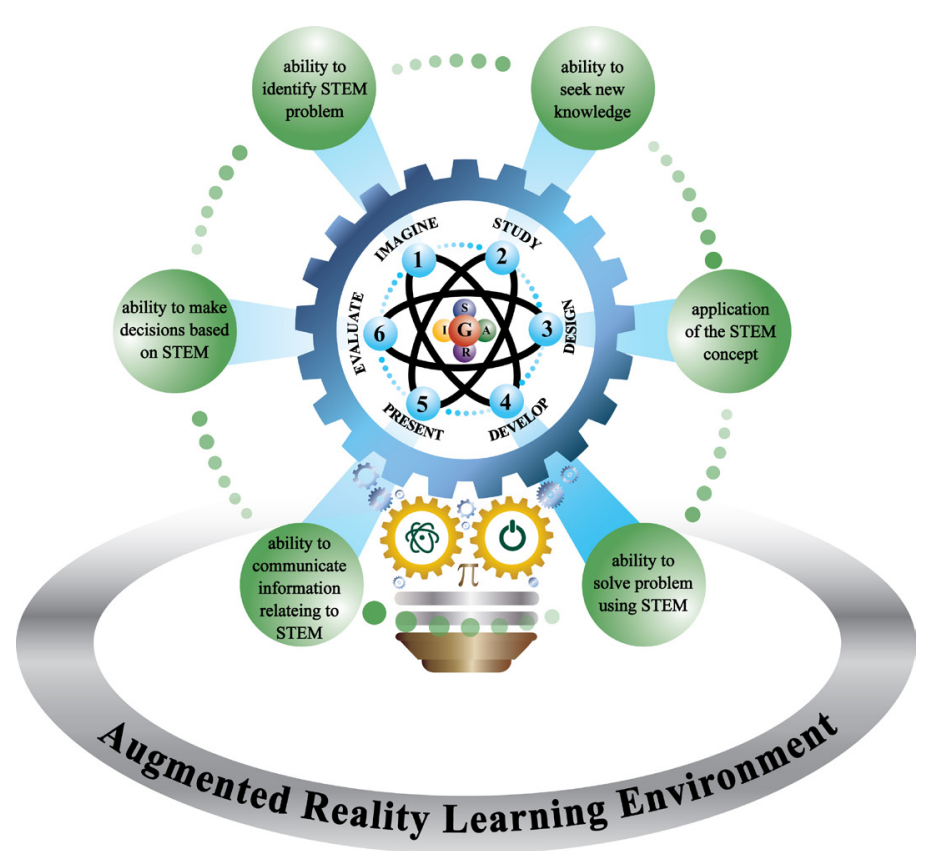

Fig. 3. The development of STEM literacy through SIGAR 
Develop: The students invented the object they designed and the teacher provided them with AR media to help them select the required materials and tools, as well as getting advice from experts, so that they developed their ability to solve problems using STEM.

Present: In groups, the students used AR to present their objects and the processes they employed to invent the object, so that they developed their ability to communicate STEM information.

Evaluation: The students scrutinized the objects and inventions of all groups through AR media. The students used the requirements and criteria in the design step to consider the cost of the objects, to decide which one they would select. This process allowed students to develop their ability to make decisions based on STEM.

The suitability of each element of STEM literacy was evaluated and certified by ten experts and revealed the following results.

Table 2 shows that experts considered all elements of STEM literacy as most suitable. The results of the experts' evaluation of STEM Literacy development during each step of SIGAR is shown in Table 3

Table 3 shows that the experts considered each step of SIGAR was able to greatly develop each element of the student's STEM literacy.

Table 2. The results of STEM literacy element evaluation

\begin{tabular}{|l|c|c|c|}
\hline \multicolumn{1}{|c|}{ STEM Literacy elements } & Mean & S.D. & Level of agreement \\
\hline Ability to identify STEM problems & 5.00 & 0.00 & Strongly agree \\
\hline Ability to seek new knowledge & 5.00 & 0.00 & Strongly agree \\
\hline Application of STEM concepts & 4.90 & 0.32 & Strongly agree \\
\hline Ability to solve problems using STEM & 4.80 & 0.42 & Strongly agree \\
\hline Ability to communicate the information relating to STEM & 4.90 & 0.32 & Strongly agree \\
\hline Ability to make decisions based on STEM & 5.00 & 0.00 & Strongly agree \\
\hline
\end{tabular}

Table 3. The results of the evaluation of STEM Literacy development during each step of SIGAR

\begin{tabular}{|l|c|c|c|}
\hline \multicolumn{1}{|c|}{ STEM Literacy development during each step of SIGAR } & Mean & S.D. & Level of agreement \\
\hline $\begin{array}{l}\text { Imagine step can develop the student's ability to identify STEM } \\
\text { problem. }\end{array}$ & 4.90 & 0.32 & Strongly agree \\
\hline $\begin{array}{l}\text { Study and research step can develop the student's ability to seek } \\
\text { new knowledge. }\end{array}$ & 5.00 & 0.00 & Strongly agree \\
\hline $\begin{array}{l}\text { Design step can develop the student's ability to apply STEM } \\
\text { concept. }\end{array}$ & 5.00 & 0.00 & Strongly agree \\
\hline $\begin{array}{l}\text { Develop step can enhance the student's ability to solve problem } \\
\text { using STEM. }\end{array}$ & 4.80 & 0.42 & Strongly agree \\
\hline $\begin{array}{l}\text { Present step can develop the student's ability to communicate } \\
\text { information relating to STEM. }\end{array}$ & 4.90 & 0.32 & Strongly agree \\
\hline $\begin{array}{l}\text { Evaluate step can develop the student's ability to make decision } \\
\text { based on STEM. }\end{array}$ & 5.00 & 0.00 & Strongly agree \\
\hline
\end{tabular}




\section{Conclusion}

There are six elements of STEM literacy - the ability to identify issues and problems, the ability to seek new knowledge, the ability to apply STEM, the ability to solve problems, the ability to communicate, and the ability to make decisions based on STEM. The experts' evaluation revealed that all six elements of STEM literacy were most suitable.

Considering the SIGAR steps in relation to the development of STEM literacy, it was found that the imagine step developed the ability to identify problems, the study step developed the ability to seek new knowledge, the design step developed the ability to apply knowledge, the develop step enhanced the ability to solve problems, the present step developed the ability to communicate and the evaluate step developed the ability to make decisions based on STEM, as these were given the highest levels of evaluation. The experts also evaluated each step of SIGAR and found that they were most suitable for the development of the respective aspects of STEM literacy.

\section{References}

[1] National Governors Association. (2007). Innovation America Building a Science, Technology, Engineering and Math Agenda. Washington, DC : National Governor's Association.

[2] Thomasian, J. ((2011. [online]. Building A Science, Technology, Engineering and Math Education Agenda. [cited 25 Jan 2015]. Available from : URL : http://www.nga.org/files/live/sites/NGA/files/pdf/1112STEMGUIDE.PDF

[3] Bybee, R. W. .(2010) “Advancing STEM Education: A2020 Vision.” TECHNOLOGY AND ENGINEERING TEACHER. Vol.70 No.1 : 30-35.

[4] Dugger, E. W. (2014). [online]. STEM: Some Basic Definitions. [cited 17 Sep 2015]. Available from : URL : http://www.iteea.org/Resources/PressRoom/STEM Definition.pdf.

[5] ITEEA board of directors. (2009). [online]. Proclamation: ITEEA's Position on the "T"\&"E" of STEM. [cited 14 Mar 2015]. Available from : URL : http://www.iteaconnect.org/AboutITEEA/STEMProclamation.pdf

[6] The United States Department of Education. (2007). Report of the Academic Competitiveness Council. Washington, DC : Author.

[7] Meeder, H . .(2014) ]online]. What Is "STEM Literacy"? . [cited 14 Aug 2015]. Available from : URL : http://nc3t.com/stem-literacy.

[8] National Research Council. (2011). Successful K-12 STEM Education: Identifying Effective Approaches in Science, Technology, Engineering, and Mathematics. Committee on Highly Successful Science Programs for K-12 Science Education. Board on Science Education and Board on Testing and Assessment, Division of Behavioral and Social Sciences and Education. Washington, DC : The National Academies Press.

[9] Zollman, A . (2012). "Learning for STEM Literacy: STEM Literacy for Learning." School Science and Mathematics. Vol.112 No.1 : 12-19. https://doi.org/10.1111/j.19498594.2012.00101.x

[10] Azuma, R. T. (1997). "A survey of augmented reality." Presence : Teleoperators and Virtual Environments. Vol.6 No.4 : 355-385. https://doi.org/10.1162/pres.1997.6.4.355 
[11] Yuen, C. S., Yaoyuneyong, G. and Johnson, E. (2011). "Augmented Reality: An Overview and Five Directions for AR in Education." Journal of Educational Technology Development and Exchance. Vol.4 No.1 : 119-140.

[12] Lee, K. (2012). “Augmented Reality in Education and Training." TechTrends. Vol.56 No.2 : 13-21 https://doi.org/10.1007/s11528-012-0559-3

[13] S. Techakosit and P. Nilsook. (2016). The Learning Process of Scientific Imagineering through AR in Order to Enhance STEM Literacy. iJET. Vol.11 No.7 : 57-63.

[14] Walt Disney Imagineering . .(2010) Walt Disney Imagineering: a Behind the Dreams Look at Making the Magic Real. China : Welcome Enterprises, Inc.

[15] Guzdial, M. and Tew, E. A. (2006). "Imagineering Inauthentic Legitimate Peripheral Participation: An Instructional Design Approach for Motivating Computing Education." ICER'06. : 51-58.

[16] Chenail, J. R. (2004). "When Disney meets the research park : Metaphors and models for engineering an online learning community of tomorrow." The Internet and Higher Education. $7:$ 107-121. https://doi.org/10.1016/j.iheduc.2004.03.001

[17] The Connectory. (2016) . [online]. Why STEM Empower the next generation of innovators. [cited 2 Aug 2016]. Available from : URL : http://theconnectory.org/why-stem.

[18] Sorgi, B. D. (2016). [online]. STEM Literacy: Fad or Future?. [cited 1 Jan 2016]. Available from : URL : http:// https://www1.iclicker.com/stem-literacy-fad-future/

[19] Purzer, S., Strobel, J. and Cardella, E. M. (2014). [online]. Engineering in Pre-College Settings: Synthesizing Research, Policy, and Practices. Purdue University Press. [cited 2 Aug 2016]. Available from : URL : http://www.jstor.org/stable/j.ctt6wq7bh

[20] Washington STEM Study Group. (2011). [online]. STEM Literacy Definition. [cited 3 Oct 2014]. Available from : URL : http://web3.esd112.org/docs/stem/stem-literacydefinition.pdf?sfvrsn=2

[21] Chae, Y., Purzer, S. and Cardella, M. (2010) . "Core Concepts for Engineering Literacy: The Interrelationships among STEM Disciplines." American Society for Engineering Education Annual Conference and Exposition . Louisville, Kentucky

\section{$7 \quad$ Authors}

Somsak Techakosit is with Kasetsart University Laboratory School Center for Educational Research and Development, Bangkok, Thailand (techakosit@gmail.com).

Prachyanun Nilsook is with King Mongkut's University of Technology North Bangkok, Bangkok, Thailand (prachyanun@hotmail.com).

Article submitted 04 September 2017. Published as resubmitted by the authors 11 November 2017. 